\title{
VALUES ORIENTATION IN BUSINESS THROUGH SERVICE INNOVATION: A CONCEPTUAL FRAMEWORK
}

\author{
Muhammad Sayem ${ }^{1}$ \\ ${ }^{1}$ Faculty of Business, Government and Law, University of Canberra, Australia \\ sayem. sayemecanberra.edu.au
}

\begin{abstract}
Service innovation evinced as the most discernible facet of service literature. It has been viewed as a strong mechanism to create value for customers, communities, business alliances and society. The emergence of service-dominant logic has brought about a radical change in terms of how value is created through service innovation. S-D logic only considers the value-in-use that is the financial value. Consequently the focus of service innovation research has remained on profit maximization only. Accordingly there is a paucity of research directed towards values-based service innovation. Couched on this notion of valuesbased service, this research will shed light on the service innovation paradigm. The theoretical dimension has been drawn from S-D logic and linked with the concept of triple-bottom line that encompasses the acuity of sustainability. A conceptual framework has been developed with some propositions. This study further suggests that more empirical research is required to further investigate values-based service innovation.
\end{abstract}

\section{Keywords}

Sustainability, Innovation, Values

\section{INTRODUCTION:}

There has been a radical paradigm shift globally from manufacturing industry towards the service industry. This change has been driven by the growing trend in the emergence of service as the dominant sector in the economy. The growing 'servitization' has been championed by a number of factors such as - globalization, technology developments, changing economic structure, [1] and above all the ever shifting consumer preferences. Seemingly product sector witnessed a plethora of innovation initiatives in the past. Because of constant growth of service sector, service innovation remains at the core of service research in recent times [2; 3;4]. Partially because of the reason is that the GDP contribution of service in the overall economy of the dominant economic forces of the world. For example - in USA 79\% comes from service sector, UK 78\%. Despite of this growing importance of service sector, it has remained the most inadequately understood part of the economy. There is a concensus that service innovation is under researched $[2 ; 5 ; 6 ; 7 ; 8]$. Consequently a growing body of researchers have enacted to this research gap during the last decade and contributed to the literature. Noticeably research undertaken in service innovation has mainly focused on economic value orientation. But it is argued that the fundamental structure of business firms has changed now-a-days. They have been regarded as 'globally integrated enterprises' which should consider the integration of economic, environmental and societal factors as the basis of doing business [9]. Therefore the primary focus

DOI: $10.5121 /$ ijmvsc.2012.3401 
of new service development should not be guided by the motive of creating value-in-use only there should be values-based approach which comes from the ethical perspective.

Accordingly a new stream of research has emerged which intertwines the values-based approach in the name of sustainability. This school of thought proposes that the goal of service business should associate the well-being of equity, social justice, human capabilities and development, ecological stability, social ecology, consumer resource development, literacy, consumer freedom/control/agency, social networks and support, happiness, and the mitigation of consumer vulnerability [3]. Drawing upon this conundrum this research seeks to examine the values-based service innovation aspect.

\section{RESEARCH OBJECTIVE:}

The objective of this paper is to conceptualize the values orientation in business through service innovation. To do that this research will shed light on the existing literature of service innovation and the emergence of ethical thinking in business. Invoking insights from the literature and grounded on the theoretical premise of S-D logic and triple-bottom line this study will construct a conceptual framework which further suggests some research propositions. As an initial approach to explore the values-driven service innovation the author also intends to broaden the overview in this trajectory through the conceptual exploration.

\section{BACKGROUND:}

This section will highlight on the existing contributions on service innovation literature and the values-based service paradigm.

\subsection{Service innovation literature:}

As regarded by a growing body of researchers innovation is a catalyst of growth in business and economy. Luecke \& Katz, [10, p.2] refers to innovation as 'the introduction of a new thing or method. Innovativeness refers to 'a firm's capacity to engage in new enterprise that is, introduction of new processes, products, or ideas in the organization' [11, p. 429]. This capacity to innovate is among the most important factors which influences the business performance and as such, innovativeness is amongst the unique culture which embeds in the tangible and intangible resources leading a firm towards successful business performance.

As posited by a number of scholars that innovation research is biased towards goods dominant view which exerts on technology oriented innovation. One of the main reasons of this biasness is due to the structural peculiarities of service which are intangibility, heterogeneity, inseparability [12]. However the 'servitization' of the dominant economic forces has changed the perception and focuses more on the operant resources [13] of the firm which are knowledge and skills, collaboration which creates new opportunities and develops new service.

\subsubsection{Incremental and radical innovation:}

Service innovation has been studied from the degree of innovation and radicalness. Radical service innovation creates brand new values through innovative concepts whereas incremental service innovation describes a new value creation through the incremental addition of existing values. $[14 ; 15 ; 16]$. 
Radical innovation often termed as discontinuous innovation or explorative innovation [17] is synonymous and widely used in service literature. It is argued that there are some innovations which can bring fundamental changes in new services that represent revolutionary changes in service benefits $[18 ; 19]$. This form of innovation in service is associated with developing new to services, creating new markets, and corresponding to needs of emerging customers and markets [20].

The other type of innovation depending on the degree is Incremental service innovation which is also termed as exploitative innovation [17]. This form of innovation involves extensions of existing product and service lines. The existing skills, knowledge and technological expertise are utilized to further improve and transform the existing offerings in an incremental manner to satisfy customers in known markets [20]. Incremental innovation is regarded as the most common form of innovation [21].

\subsubsection{Assimilation and demarcation- A synthesis approach:}

The service literature also entails the nature, type and causes of innovation which are well documented in a number of studies. Coomb and Miles [22] propose three different approaches: Assimilation, Demarcation and Synthesis.

Proponents of assimilation approach argue that innovation in the service sector is similar to manufacturing industry which is fundamentally driven by technology. Majority of the service innovation literature consists of assimilation approach [22; 23; 24]. However, this approach has been strongly criticized due to over emphasizing technology based innovation $[12 ; 25]$ and not considering the core service characteristics like intangibility, co-production [25; 26]. Drejer [27] in line with Coombs and Miles [22] condemn that this approach limits the innovation in a narrow perspective for understanding the dynamics of services as well as manufacturing.

Acknowledging the structural differences between product and service some experts have advocated the 'Demarcation' approach [28;29]. The primary focus of demarcation approach is not to compare innovation in services directly with innovation in manufacturing, but rather to study distinctive features of service innovation [30]. However this approach is not free from criticism as well due over emphasize services' distinctive features, thus restricting the generality of their findings [27].

A synthesis approach has emerged and attained considerable attention in service innovation literature. In spite of its growing importance yet it is a nascent stream of research and least developed approach (Castro et. al. 2011) compared to the other two opposite continuum of service innovation literature. A Synthesis approach underpins that services and manufacturing innovation need not use completely different perspectives. The synthesis approach is grounded on the S-D logic which attributes service as the fundamental basis of exchange between two parties $[12 ; 31]$. The study of Gallouj and Weinstein [32] provides a comprehensive framework for synthesis approach. Their study entails a broader framework of innovation aspects giving less focus to either manufacturing industry or service industry. By doing that it considers both the elements of technological and non-technological innovation. Gallouj and Weinstein [32] build their approach on a model that represents a product or a service as a system of competences, technical characteristics and final characteristics. Innovations thus consist of changes in one or more of these elements. It is noticeable that both the assimilation and demarcation is based upon G-D logic which conceptualizes service as a supplementary aspect of physical products [33] thereby undermining the real importance and contribution of service sector. The innovation process is analyzed by merely extending or adapting some individual insights developed in 
manufacturing contexts. Therefore the synthesis approach has been considered more scientific. This research will be based on synthesis approach by considering the fact that value is co-created and appears to be experiential by only the party who benefits from it. A service innovation is further expansion of value offered in a manner which is not recognized or experienced before.

\subsection{Values-driven service:}

From service innovation trajectory the link of values-based has been found in the study of Edvardsson and Enquist [34]. This study posits that the aim of service innovation should not be confined within creating 'economic value'. It should also be guided by 'ethical value'. By saying this, they posited the shift from 'value' towards 'values'. They further expand the word 'values' by saying "such values include the principles, standards, ethics, and ideals that guide the actions of people and organizations alike" [34, p.2]. Services developed through this "values-based' approach not only suffice to the sustainability motives but also become benchmark values which are far more enduring and stable [34]. They support their arguments with empirical evidences derived from a number of successful business firms who applied all the three pillars of sustainability or triple-bottom line. Therefore new opportunities can be crafted in offering values with the notion of values-based approach.

Despite a number of scholars have envisioned sustainability and its relationship with successful business performance the empirical evidences are scarce. This research gap is more evident in the service literature $[12 ; 20]$. Therefore this research will conceptualize these important phenomena with a holistic framework which will interconnect the values-driven approach, i.e. the sustainability and service innovation.

\section{THEORETICAL FRAMEWORK:}

The theoretical foundation of this research is based upon two different overarching concepts. Primarily the service innovation has been viewed through an S-D logic perspective. Therefore the framework adopted in the study is grounded in the study of Vargo and Lusch [13]. The second theoretical pillar of this research is 'triple bottom-line' which envisions the concept of sustainability with the aim of sustainable development. The following section will describe the two concepts and how this research integrates the two into the conceptual framework.

\subsection{Service-dominant logic:}

Service-dominant (S-D) logic introduces a new paradigm opposing the traditional goodsdominant (G-D) logic paradigm [13]. The S-D logic in recent times has been regarded and recognized as a potential theoretical foundation on which a science of service can be developed [35]. S-D logic proposes that market exchange is the process of parties using their specialized knowledge and skills for the benefit of other parties. In other words, exchange is driven by reciprocal and mutually beneficial service provision. Vargo and Lusch [13] underpin two types of resources that make this service provision- the operant resources (knowledge, skill and all the intangible resources) and the operand resources (tangible resources). The association of these two resources helps the firm to develop the service provision which have been termed as "value-inuse". S-D logic is rooted in ten foundational premises (FPs) that establish a dynamic, servicecentered framework for exploring exchange-related phenomena [13].

Noticeably the concept introduced in SD-logic, as a process in which one applies resources to benefit another, is not a new or novel concept [36]. There are a number of other scholars who 
have already shed light in this perspective that service as the central to value creation and exchange [26]. The fact that makes this concept unique is that it does not consider service as a substitute for goods rather views service as superordinate to goods dominant logic [13].

The goods dominant logic is premised on the work of Smith [36]. Guided by the normative goal of increasing national wealth, Smith focused more on measurable, - what he called "nominal," sources of value, particularly tangible, exportable resources and the price paid for them in the market - "value-in-exchange." The concept was further intensified by the industrial revolution when economists desired to make economics Newtonian science [37] Within G-D logic, value is considered by economic exchange between a producer and consumer. The basis of all economic exchanges concentrates on manufacturing and distribution activities and considers value to be created by the firm and destroyed (consumed) by customers [13]. Service has been considered just as an intangible (inferior to goods) unit of output of goods that are manufactured by the firm. Thus service as a highly contributing part of the economy has largely remained diluted in the essence of good dominant logic. With the recent shift in economic activities the G-D logic perspective was enhanced with the concept of goods to service. Partly because of the reason is that an increasing number of market offerings which cannot be categorized as goods due to their intangibility and heterogeneity. However, in S-D logic, service has been conceptualized as a process of applying resources for the benefit of one party to another and core basis of exchange. This transcendence of service establishes relationship with G-D logic which fundamentally underlies within S-D logic termed as a 'Nested relationship' [13]. This nested relationship underpins and broadens the scope of SD logic over GD logic in service research.

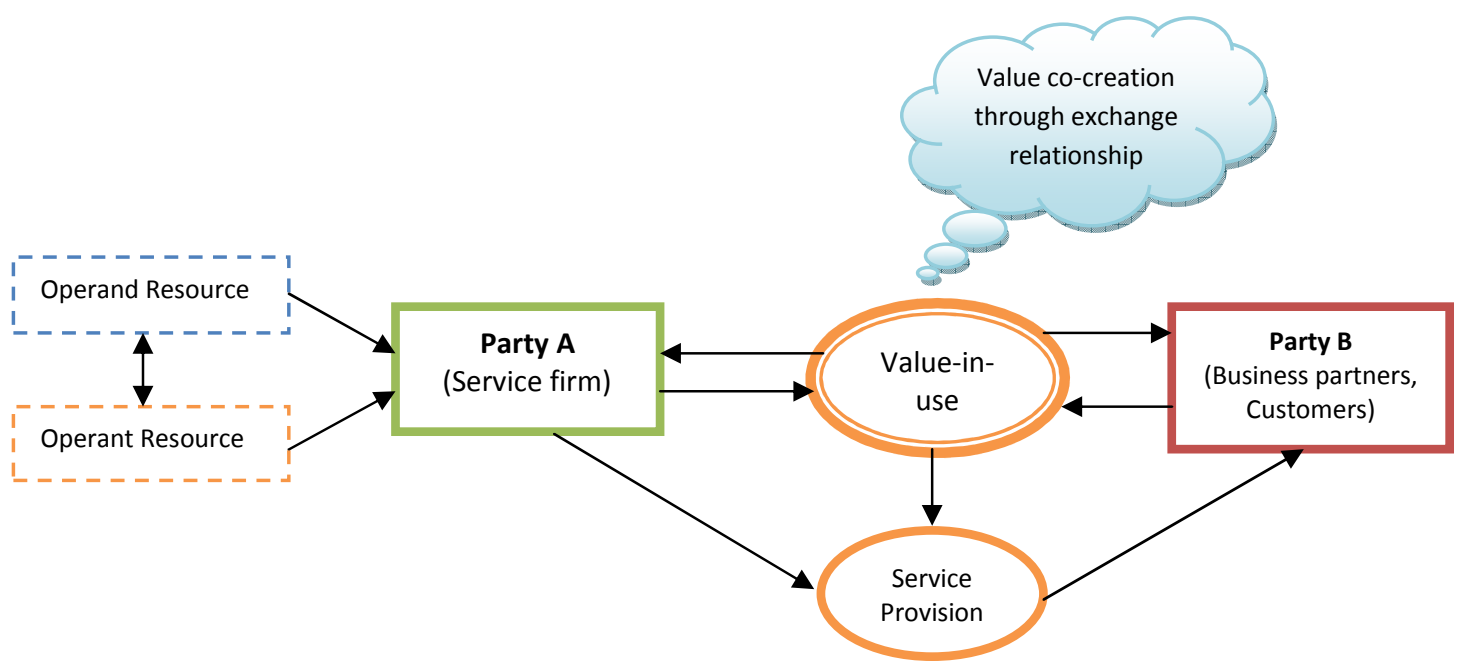

Figure- 1: An S-D logic perspective of value creation

The S-D logic perspective has been widely accepted by researchers of service science as a foundational premise for studying service innovations [12]. The core reason behind that it underscores service and tangible goods into an integrated, overarching service view [36]. Besides, it also represents a shift from static to dynamic resources with a stakeholder rather than a customer-centric perspective such as those of employees, value creation partners, and customers [52]. Michel et al. [38] further adds by saying that the S-D logic moves away from perspectives traditionally 'rooted in technological product inventions'. Therefore this study bases on the fundamental premises of S-D logic. 


\subsection{Triple-bottom line:}

The emergence of sustainability as a concept in business generated considerable interests amongst practitioners, researchers and policy makers after the publication of Brundtland Commission's report 'Our Common Future' [39] which defined it as:

"Sustainable development is development that meets the needs of the present without compromising the ability of future generations to meet their own needs."

The changing needs of stakeholders, technological development and economic pressures contribute to the need for organizations to change significantly the ways in which they think and act [40]. Recent evidences shows that orientation towards sustainability has grown from being a movement focused on environmental concerns, to a widely accepted framework that the decision making of individuals, business firms, society and governments to balance the concerns of ecological, economic, and social needs of the current and future generations. The essence of this form of development is a stable relationship between business activities and the natural world, which does not diminish the prospects for future generations to enjoy a quality life [41]. Under this setting the quest for sustainability has started to transform the competitive landscape [42] which eventually leads companies to change the way they manage products, services, technologies and business models. Despite the growing interest towards sustainability, research on sustainability and its role has remained as a fluid concept and the evidences are anecdotal. However, since 1992s "Earth Summit" in Rio de Janeiro, there has been a global consensus that sustainable development should encompass at least economic growth, social progress, and stewardship of the environment [43]. Therefore 'Sustainability' in business is considered in terms of three pillars, economic, social, and environmental considerations [44] alternatively termed as "triple-bottom line".

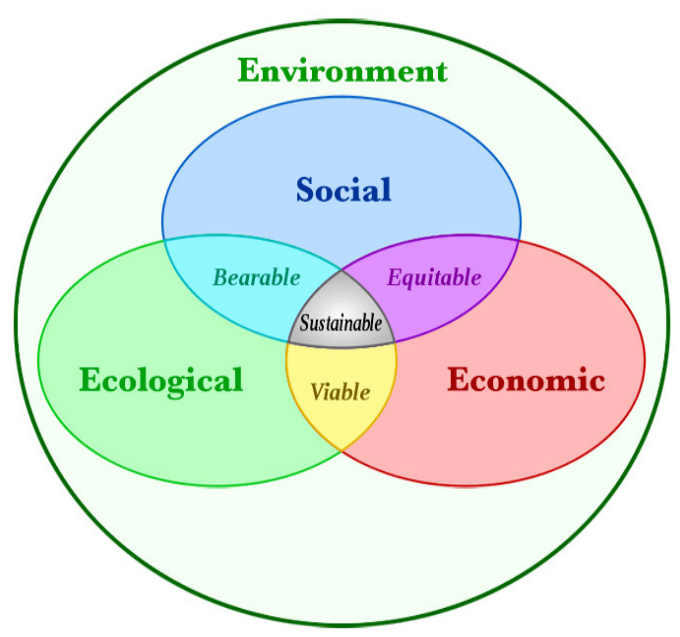

Figure-2: The sustainability paradigm.

Due to its versatile and pervasive role Sustainability has been examined from various viewpoints [45]. Chabowski et al., [46] emphasizes that, a firm can perform better when its activities are performed taking account of all three dimensions of sustainability. The marketing literature exhibits sustainability in creating opportunities and driving firm performance by taking up social 
initiatives understood as corporate social responsibility. The role of operations in making a business perform on the parameter of sustainability has been discussed as a determinant of a firm's ability to produce or deliver efficiently [47]. Firms try to create a balance among these three dimensions of sustainability to secure a safer future for their business [48]. Academic researchers mostly considered the dimensions of sustainability based on practices internal to the organisation in an individual format of planning, production, business ethics or environmental management but not in an integrated format $(49 ; 50]$. In a similar vein a number of researchers have stressed that $[51 ; 52 ; 53]$ business should be driven by an ethical vision which will endeavor to maintain the interest of all groups and parties related. So it can be inferred that a sustainable business practice involves a shared value creation for all the customer and stakeholders based on social and environmental goals. Edvardsson and Enquist [52] termed it as "value-based thinking".

\subsection{Integration of the both theoretical dimension:}

It is evident that the S-D logic introduces a revolutionary shift in management perception regarding value offerings (goods or services) through value co-creation. This certainly establishes the dominance of service sector often outdistanced by product orientated paradigm. This paradigm shift has literally changed the view that how innovation is seen and interpreted in organizations [12]. Interestingly this also has unveiled a vast array of services led by information technology. Services like Facebook, e-Bay, online banking which are co-created by the consumer has revolutionized the way services could be delivered ever.

However, the S-D logic though elucidates the concept of 'value-in-use' or 'value co-creation' it doesn't consider any ethical content [54]. The growing attention towards sustainable thinking in business has not been considered in S-D logic which is a major gap of this concept. Therefore it is believed that the integration of sustainability aspect will allow S-D logic to have a broader view and reflect its implicit assumptions regarding business ethics. Therefore this research will attempt to link the S-D logic with the triple-bottom line which is fundamentally suited in the ethical aspect of business.

Sustainable thinking starts with 'values' orientation [52] which is grounded in the ethical dimension and enforces a business towards being responsible for the well being of human society coupled with economic objectives. Therefore, the service or value offerings should be intertwined with 'values'. A values-based business is thus based on a combination of core company values and foundational values that guide a company in creating customer value and a sustainable service business $[52 ; 53]$. When the value-in-use is benchmarked by ethical values then those becomes invariably more stable and enduring compared to those with transitory market offerings for profit-only motives [52].

\section{THE CONCEPTUAL FRAMEWORK:}

The conceptual framework is grounded on the existing literature gap and the theoretical framework underscored above. 


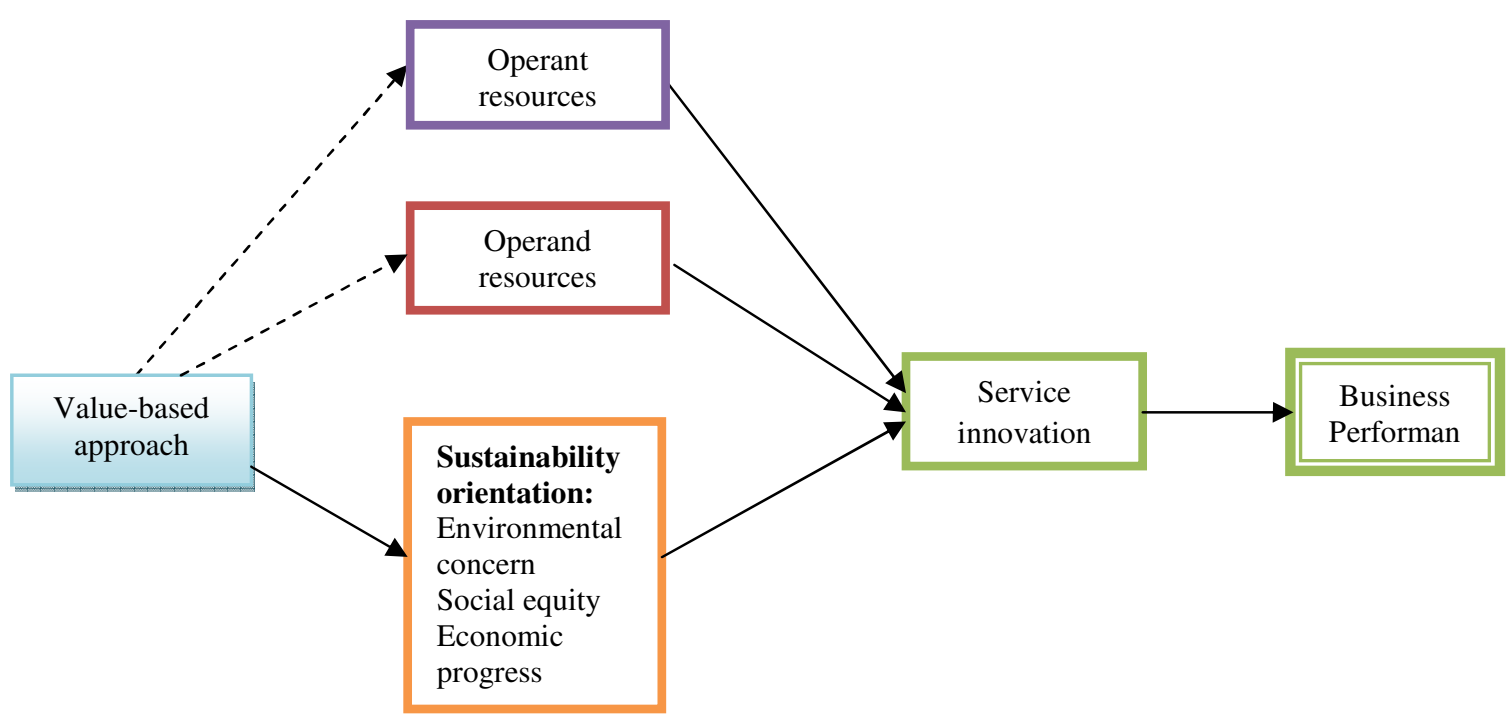

Figure-3: A conceptual framework of values-driven service innovation

\section{RESEARCH PROPOSITIONS:}

Based on the above conceptual framework this research proposes the following:

P1: The greater the integration of operant resources of the firm, the greater the possibility to innovate value-in-use.

P2: The greater the integration of operand resources of the firm, the greater the possibility to innovate value-in-use.

P3: Sustainability orientation evinces from a values-driven approach.

P4: Sustainability orientation drives the innovative business performance.

P5: Service innovation performance is positively linked with business performance.

\section{CONCLUSION, LIMITATIONS AND FUTURE RESEARCH:}

This paper makes contribution to an understanding of the values-driven service innovation paradigm. The proposed model can be considered novel in that, the model intertwine the S-D logic and triple-bottom line. Research shows that sustainability is a driver of organizational and technological innovations which yield both bottom-line and top-line returns [42]. Because of the conceptual prominence of sustainability in business, this research suggests that further empirical research is required in analyzing the values-driven service innovation. This paper has also some obvious limitations. Firstly, the conceptual model has not been tested with empirical evidences. Therefore the inferences are mere conceptual exploration based on the literature and theoretical dimension. Secondly, it integrates some of the theoretical issues surrounding values-based approach and service innovation rather than presenting a holistic view in relation to business performance.

This study also suggests that further empirical research would facilitate the appropriate understanding of the phenomena. Besides, the construct would vary based on the manufacturing industry and service industry, therefore an industry specific examination would be rather appropriate. 
International Journal of Managing Value and Supply Chains (IJMVSC) Vol. 3, No. 4, December 2012

\section{ACKNOWLEDGEMENT:}

The author would like to thank and acknowledge the editor and the anonymous reviewer for their efforts and decisions for this conceptual paper. This research is still at the early stage and further comments and guidance would help to enrich the specific phenomena.

\section{References:}

1. O'Cass, A., Song, M. \& Yuan, L. (2012) "Anatomy of service innovation: Introduction to the special issue", Journal of Business Research (in press)

2. Ettlie, J. E. \& Rosenthal, S. R. (2012),"Service innovation in manufacturing", Journal of Service Management, Vol. 23, no.3, pp440 - 454.

3. Ostrom, A.L., Bitner, M. J., Brown, S.W. Burkhard, K.A., Goul, M. Daniels, V.S., Demirkan, H. (2010) "Moving Forward and Making a Difference: Research Priorities for the Science of Service" Journal of Service Research, Vol. 13, no.1, pp4-36.

4. McKee, D. (2008) "Services, growth poles and advanced economies Service Business" An International Journal, Vol. 2, no. 2, pp99-107.

5. Castro, L. M., Montoro-Sanchez, A. \& Ortiz-De-Urbina-Criado, M. (2010) "Innovation in services industries: current and future trends", The Service Industries Journal, vol.3, no.1, pp7-20

6. Camacho, J. A. \& Rodriguez, M. (2008) "Patterns of innovation in the service sector: some insights from the Spanish innovation survey", Economics of Innovation and New Technology, vol. 17, no.5, pp459-471

7. Bitner, M., \& Brown, S. (2008) "The service imperative". Business Horizons, vol. 51, pp39-46.

8. Lusch, R., Vargo, S. \& Obrien, M. (2007) "Competing through service: Insights from servicedominant logic" Journal of Retailing, vol.83, no.1, pp5-18.

9. Palmisano, S.J. (2006) "The globally integrated enterprise". Foreign Affairs, vol. 85, no. 3, pp127-136.

10. Luecke, R \& Katz, R (2003) "Managing Creativity and Innovation", Harvard Business School Press, MA.

11. Hult, G.T.M., Hurley, R.F. \& Knight, G.A. (2004) "Innovativeness: its antecedents and impact on business performance", Industrial Marketing Management, vol. 33, pp. 429-38.

12. Ordanini, A. \& Parasuraman, A. (2011) "Service Innovation Viewed Through a Service-Dominant Logic Lens: A Conceptual Framework and Empirical Analysis". Journal of Service Research, vol.14, no.3.

13. Vargo, S. L. \& Lusch, R. F. (2004). "Evolving to a New Dominant Logic for Marketing”. Journal of Marketing, vol. 68, no.1, pp1-17.

14. Cheng, C. C. \& Krumwiede, D. (2012) "The role of service innovation in the market orientationnew service performance linkage", Technovation, vol.32, pp487-497.

15. Garcia, R. \& Calantone, R., (2002) "A critical look at technological innovation typology and innovativeness terminology: a literature review". Journal of Product Innovation Management, vol.19, pp110-132.

16. Paswan, A. D'Souza, D. \& Zolfagharian, M.A., (2009) “Toward a contextually anchored service innovation typology". Decision Sciences, vol. 40, no.3, pp513-540.

17. March, J.G. (1991), "Exploration and exploitation in organizational learning", Organization Science, Vol. 2, No.1, pp71-87. 
International Journal of Managing Value and Supply Chains (IJMVSC) Vol. 3, No. 4, December 2012

18. Berry, L. L., Shankar, V., Parish, J.T., Cadwallader, S. \& Dotzel, T. (2006) "Creating New Markets through Service Innovation,” Sloan Management Review, vol.47, no.2, pp56-63.

19. Nijssen, E. J. Hillebrand, Vermeulen, P.A.M. \& Kemp, R.G.M. (2006) “Exploring Product and Service Innovation Similarities and Differences", International Journal of Research in Marketing, Vol.23, no. 3, pp241-251.

20. McDermott, C.M. \& Prajogo, D.I. (2012)"Service innovation and performance in SMEs", International Journal of Operations \& Production Management, Vol. 32 no. 2 pp216 - 237.

21. Bell, S., Whitwell, G. \& Lukas, B. (2002) "Schools of thought in organizational learning". Journal of the Academy of Marketing Science, vol.30, no.1, pp70-86.

22. Coombs, R., Miles, I. (2000) "Innovation, measurement and services: the new problematic. In: Metcalfe, J.S., Miles, I. (Eds.), Innovation Systems in the Service Economy. Measurement and Case Study Analysis. Kluwer Academic Publishers, Boston, pp. 85-103.

23. Mansury, M.A., \& Love, J.H. (2008) "Innovation, productivity and growth in US business services: A firm-level analysis”. Technovation, vol.28, no.1-2, pp52-62.

24. Maglio, P. P. \& Spohrer, J. (2008) "Fundamentals of Service Science". Journal of the Academy of Marketing Science, vol.36, no.1, pp18-20.

25. Lusch, R. F. \& Vargo, S. L. (2008) “Service-Dominant logic: continuing the evolution” Journal of the Academy of Marketing Science. Vol. 36, no.1, pp1-10.

26. Gronroos, C. (2000) "Service Management and Marketing: A Customer Relationship Management Approach". West Sussex, UK: John Wiley and Sons.

27. Drejer, I. (2004) "Identifying Innovation in Surveys of Services: A Schumpeterian Perspective", Research Policy, vol.33, no.3, pp551-562.

28. Tether, B.S. (2005) "Do services innovate (differently)? Insights from the European innobarometer survey". Industry and Innovation, vol.12, no.2, pp153-184.

29. Djellal, F., \& Gallouj, F. (2000) "Innovation Surveys for Service Industries: A Review. Paper presented at the DG Enterprise Conference on Innovation and Enterprise Creation: Statistics and Indicators", Sophia Antipolis, France.

30. Sundbo, J., Gallouj, F. (2000) "Innovation as a loosely coupled system in services. In: Metcalfe, J.S., Mile ,I. (Eds.), Innovation Systems in the Service Economy. Kluwer Academic Publishers, Boston, pp. 43-68.

31. Gallouj, F., (2000). Beyond technological innovation: trajectories and varieties of services innovation. In: Boden, M., Miles, I. (Eds.), Services and the Knowledge-Based Economy. Continuum, London, pp. 129-145.

32. Gallouj, F. \& Weinstein, O. (1997) "Innovation in services”, Research Policy, vol.26, pp537-556.

33. Hauknes, J., (1998) Services in innovation-Innovation in services, SI4S Synthesis Papers S1, STEP, Oslo.

34. Edvardsson, B., \& Enquist, B. (2011) "The service excellence and innovation model: Lessons from IKEA and other service frontiers", Management \& Business Excellence, Vol.22, no.5, pp535-551.

35. Vargo, S. L. \& Lusch, R. F. (2010) "Handbook of service science, Research and Innovations in the Service Economy", pp 133-156.

36. Lusch, R. F. \& Vargo, S. L. (Eds.) (2006) "The Service-Dominant Logic of Marketing: Dialog, Debate, and Directions". Armonk, New York: M.E. Sharpe. 
International Journal of Managing Value and Supply Chains (IJMVSC) Vol. 3, No. 4, December 2012

37. Vargo, S. L. \& Morgan, F. W. (2005) "Services in Society and Academic Thought: An Historical Analysis”. Journal of Macro marketing, vol.25, no.1, pp42-53.

38. Michel, S., Brown, S.W. \& Gallan, A.S. (2008) "An Expanded and Strategic View of Discontinuous Innovations: Deploying a Service-Dominant Logic", Journal of the Academy of Marketing Science, vol.36, no.1, pp54-66.

39. Brundtland, H., (1987) Our Common Future. Oxford University Press for World Commission on Environment and Development, Oxford University Press., Oxford.

40. Brown, S.L. \& Eisenhardt, K.M. (1998) Competing on the edge: Strategy as strategy chaos, Harvard Business School Publication, Boston, MA.

41. Mintzer, I.M. (1992) "Insurance against the heat trap: Estimating the costs of reducing the risks, in Pearman, G.I. (ed.), Limiting the greenhouse effect: Options for controlling atmospheric CO2 accumulation, John Wiley, New York.

42. Nidumolu, R. Prahalad, C.K. \& Rangaswami, M.R. (2009) "Why sustainability is now the key driver of innovation", Harvard Business Review, September.

43. Tanzil, D. \& Beloff, B.R. (2006) "Assessing impacts: Overview on sustainability indicators and metrics”, Environmental Quality Management, Vol. 15, no.4, pp41-56.

44. Morrisson-Saunders, A. \& Therivel, R. (2006) "Sustainability integration and assessment", Journal of Environmental Assessment Policy and Management, vol.8 no.3, pp 281-298.

45. Sheth, J.N. Sethia, N.K. \& Srinivas, S. (2011) "Mindful consumption: a customer-centric approach to sustainability", Journal of the Academy of Marketing Science, Vol. 39, no.1, pp 21-39.

46. Chabowski, B. R., Mena, J. A., \& Gonzalez-Padron, T. L. (2011) "The structure of sustainability research in marketing, 1958-2008: a basis for future research opportunities". Journal of the Academy of Marketing Science, vol. 39, no.1, pp55-70.

47. Dao, V. Langella, I. \& Carbo, J. (2011) "From green to sustainability: Information Technology and an integrated sustainability framework, Vol. 20, no.1, pp63-79.

48. Cronin J.J., Smith, S.J. Gleim, M.R. Ramirez, E. \& Martinez, J.D. (2011) “Green marketing strategies: an examination of stakeholders and the opportunities they present", Journal of the Academy of Marketing Science, Vol. 39, no.1, pp158-174.

49. Amit R. \& Zott, C. (2001) "Value creation in E-business" Strategic Management Journal, Vol. 22, no.6-7, pp493-520.

50. Charter, M. \& Clark, T. (2008) "Product sustainability: organisational considerations", International Journal of Product Development, Vol.6, no. 3-4, pp251-275.

51. Gummesson, E. (2008) Total relationship marketing. 3rd edn., Butterworth- Heinemann, Oxford.

52. Edvardsson, B., \& Enquist, B. (2009) "Values-based service for sustainable business - lessons from IKEA”. London: Routledge.

53. Enquist, B., Edvardsson, B., \& Sebhatu, S. (2008) "Corporate social responsibility for charity or for service business”? The Asian Journal of Quality, vol.9, no.1, pp55-67.

54. Abela, A. V. \& Murphy, P.E. (2008) "Marketing with integrity: ethics and the service dominant logic for marketing", Journal of the Academy of Marketing Science, vol.36, no.1, pp39-53. 
International Journal of Managing Value and Supply Chains (IJMVSC) Vol. 3, No. 4, December 2012

\section{About the Author:}

Muhammad Sayem is a Doctoral candidate at the Faculty of Business, Government and Law, University of Canberra, Australia. He has got more than 6 years of professional experience in the service sector in some multi-national companies. Derived from his professional experience he endeavors to extend his knowledge in the field of service innovation. He aspires to explore the paradigm of values-based service innovation, sustainability and its relationship with business performance.

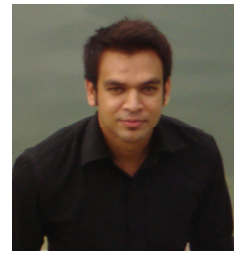

